\title{
PATIENTS VISITING INTENTION: A PERSPECTIVE OF INTERNAL AND SOCIAL MEDIA MARKETING IN KAMBANG JAMBI HOSPITAL
}

\author{
Yulhasmida $^{1}$; Syahmardi Yacob ${ }^{2}$; Tona Aurora Lubis ${ }^{3}$ \\ ${ }^{1}$ Director of Aulia Hospital Pekanbaru, Riau \\ ${ }^{2.3}$ Magister Management, the Graduate School of Universitas Jambi \\ Corresponding Authors : yulhasmida17@gmail.com
}

\begin{abstract}
In the digital era, the use of the internet is a necessity. The role of social media should be utilized as well as a means of cheap promotion for hospitals. This quantitative study aims to examine the effect of internal marketing on social media, the effect of internal marketing on the interest of patient visits, and the effect of social media on the interest of patient visit Kambang Hospital in Jambi. The respondents involved in this study were all employees in Kambang Hospital, totaling 251 people. Moreover, the questionnaire was distributed by utilizing the google doc application so that the data was immediately tabulated. Additionally, the results of the study were tested using the Smart PLS 2.0 application. As $181(72 \%)$ respondents responded the questionnaires on 13 indicators of internal marketing (IM) variable, 4 indicators of social media (SM) variable and 4 indicators of patient visit interest (PTI) variable. In brief, the results of the study proved that; 1) there was the significant effect of IM on the Constitutional Court, 2) there was the significant effect of IM on SM, 3) there was the significant effect of SM on the Constitutional Court, and 4) there was indirect effect of IM on PTI through SM by using significant Sobel test calculations. This indicated that internal marketing can affect the interest of patient visits through the use of social media.
\end{abstract}

Keywords: internal marketing, social media, the interest of patient visit

\section{Background}

Internet and social media are the significant communication. In digital and industry 4.0 era, the influence of social media is very pronounced in building image, both for employees and consumers, micro and macro scale industries, including in services and goods. One of the service industries have to use an internet technology as a method of marketing services in various social networks, such as websites, blogs, vlogs, youtube, instagram, whatsapp to Facebook. According to 'We are Social Data' the number of active users in 2017 was 106 million, and as the one of the largest in the world. Even 54.56\% of Indonesia's population (143.3 million people) have used the internet (APJII, 2017).

Social media is cheaper than using direct markets in marketing management, because its can create opportunities to market services into virtual customers and not separated by distance and time. Through social media, people can interact and exchange any information, so can be used as an easy advertising and distributing too.

As in marketing digitalization, an industrial development also requires consumers. In this case, consumers as end users certainly need service quality as return on what they have paid. One example of an industry was used it is a hospital where patients as consumers are must be supported by quality of service from employees. Kotler (2009), if the industry really wants to satisfy its customers, employees must be prioritized, not customers. Furthermore Kotler (2009) good industry management is a good in relations with employess who will positive affect with customers. Chang and Chang (2007) the job satisfaction has a positive effect on organizational commitment, nurses' perception of internal marketing has a positive effect on job and the perception of internal nurse marketing has a positive effect in an organizational commitment. Therefore management should carry out internal marketing and provide support to employees to produce a good performance.

Zeithaml and Bitner (1996) the role of employees are in the front and support it in the back for servicing organization successfully, because in addition the employees has a role as an organizational representation and building positive perception of buyers. Employees are services themselves, employees are organizations in the consumers perception, and employees are the marketers. Therefore, industries including hospitals, need to have strategies it can be support the work of employees in carrying out marketing functions, as known as an internal marketing. 
Internal marketing treats employees and consumers with equal interests through proactive programs as the aim of organizational achievement. Payne (1993, in Farzad et al. 2008) said that an objective key of internal marketing is internal and external development of consumer awareness and the removal of barriers to achieve the effectiveness in organization. Therefore, internal marketing has a strong influence to employees, sense of belonging, isolation, and work motivation (Kudo et al., 2006). In hospital managerial, internal marketing is a necessity that must be done by employees, through social media in order to increasing a patient visiting intention.

This study examines the role of internal marketing as a support for connect with patient through social media, which is based on previous studies (Chang and chang, 2007; Kudo et al., 2006; Greene at al., 1994). This research is also expected to provide benefits for the development of theories, especially related to internal marketing.

\section{Literature Review}

Internal Marketing

Gronroos (1990) internal marketing as a philosophy management which an understanding to managers and appreciation for the role of employees in the company. Kotler (1997) internal marketing as an effort by serviced of companies to train effectively and employees motivation in dealing with customers and support services to work as a team in providing customer satisfaction. Rafiq and Ahmed (2000), internal marketing is an effort to integrate and inter-operate the all strategy in a company's managerial as a marketing method.

Amangala, E.A., (2013) internal marketing positively correlates with employee performance, rewards and organizational commitment. Rafiq and Ahmed (2000) an internal marketing model (from combination of Berry and the Gronroos model, 1991). This model highlights the importance of employee attitudes in service quality and customer satisfaction.

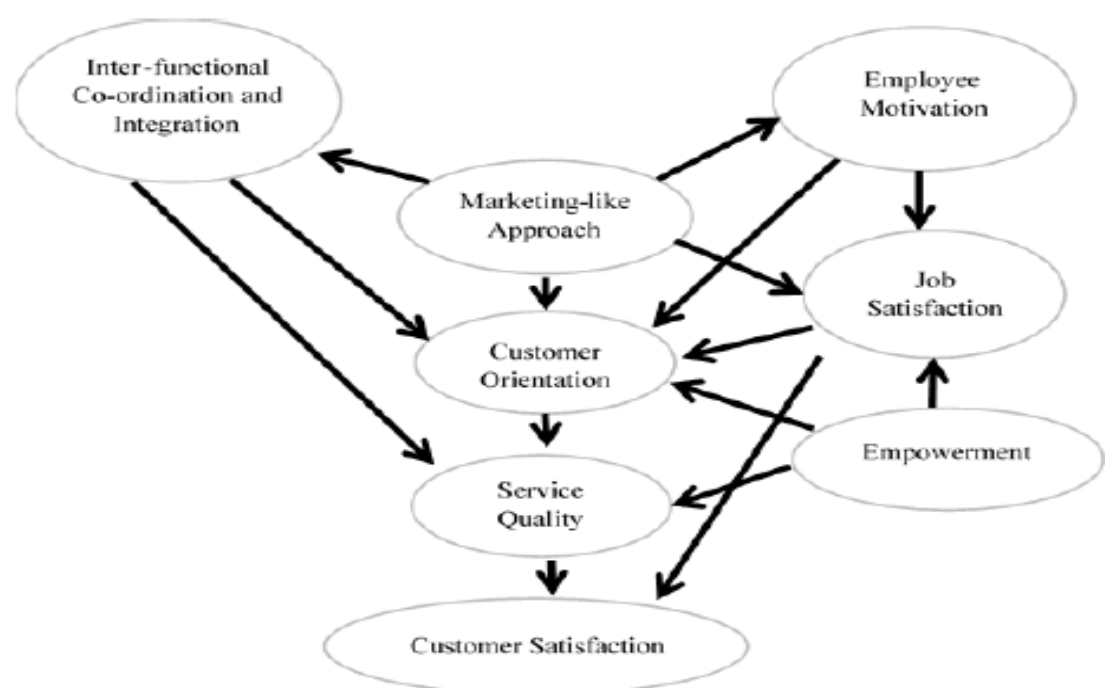

Source: Ahmed dan Rafiq, $2002: 20$

Figure 1: Internal Marketing Model

Customer satisfaction is the goal and marketing tool. Customers in hospital are the patients, if the patient satisfied through the quality of service, they will bring it more patients to visits the hospital through positive word of mouth (Bhaskar L.N., et al 2012).

\section{Social Media Marketing}

Social media is a change in the people discovery, read, and share news, information and content. Social media has become popular because people can connecting in online world, can be used as a form of personal, political and business relations (Wikipedia.2019, accessed on February 13, 2019). Philip Kotler (2012), the pattern of marketing through social media allows interaction between producers and consumers of their products. Consumer satisfaction will spread to their collegues, and this effect cannot be done through advertising. 
Long X, et al. (2017) in his study to 665 respondents showed a significant increase in social media usage over the past three years among urologists in Eastern China, and those under 35 years age were independent predictors of social media users. More respondents said the social media for professional purposes than personal use, and social media has a positive impact on their professional practice.

\section{Patient Visiting Intention}

Trendis (1980) states intention is someone's desire which influenced by social factors, feelings and perceived consequences. Furthermore Davis et al. (1989) suggested the benefits felt by patients would be increasing their interesting in revisit again. Ramadan (2015) visiting intention is basically a drive from the consumer in the form of attract to revisit in this area.

According to Cronin and Taylor (1992) customers respond positively to the service quality of a company and eventually generate buying interest in the company or interest in product repurchasing. Whereas Thomson, et., al, (1991) states that one's belief in the product will increase their interest and in the end the individual will use the product as a reference.

Related to this study, the measurement of patient visit intention is using the concept put forward by Ferdinand (2002), namely purchase intention (in this study called patient visit intention) can be identified through the following indicators: 1) Transactional interest, the tendency of someone to buy product. 2) Referential interest, the tendency of someone to refer products to others. 3) Preferential interest, interest in describes the behavior of someone who has the main preference for the product. 4) Interest in explorations, someone behavior who's looking for information about the product which is interesting it and looking for information to support it.

\section{Research Framework}

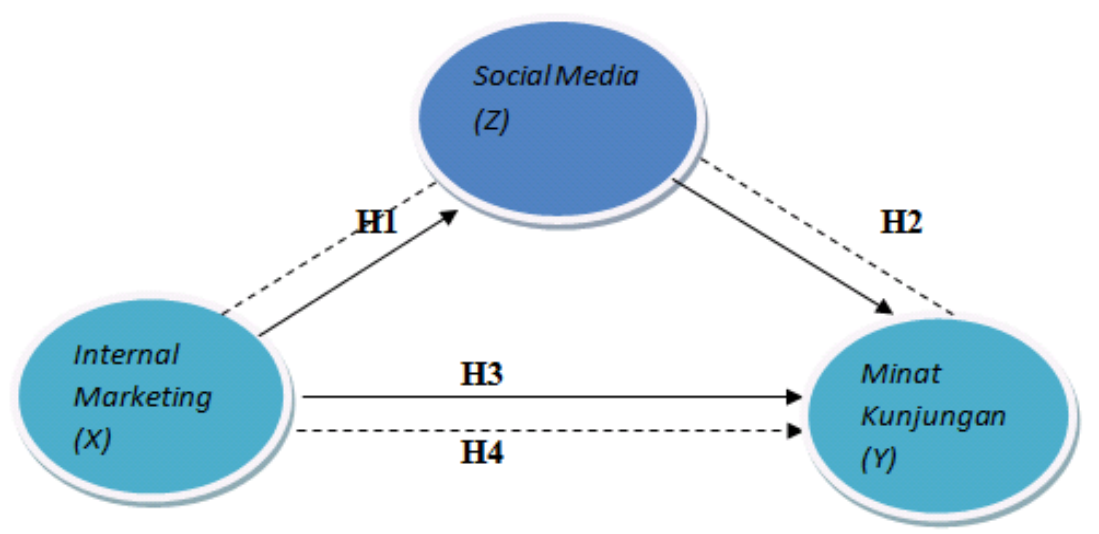

Figure 2: Research Framework

\section{Research Method}

This study used a survey method with questionnaires distributed to respondent using the Google doc application as a primary data, while secondary data was obtained from medical records in Kambang General Hospital and from other relevant sources. Data was processed using the Smart PLS 2.0 application. The respondents of the study were employees of Kambang Hospital, totaling 251 people, both inquiries on employee satisfaction surveys and questions on patient satisfaction surveys. The assessment standard uses a Likert scale and 5 alternative answers to respondents.

This study consists of exogenous variables (X), namely Internal Marketing which consists of; (X1) job satisfaction, with 4 parameters, namely; 1) career management (X1.1), 2) education and training (X1.2), 3) reward (X.3), and 4) employee recruitment systems (X1.4). (X2) patient satisfaction, within 9 parameters, namely: 1) doctor services (X2.1), 2) nurse services (X2.2), 3) information and registration services (X2.3), 4) laboratory services (X2 .4), 5) services in Radiology (X2.5), 6) financial officers services (Cashier) (X2.6), 7) Nutrition/food services (X2.7), 8) pharmacy services (X2.8) and 9) facilities, infrastructure and cleanliness of Kambang Hospital

An endogenous variable (Y), Patients visit intention. This variable is measured by positive or negative achievement as a response based on experience or information. This variable are transactional (Y1), referential (Y2), preferential (Y3) or explorative (Y4) intention emerge from the research object. 
Intervening variable (Z) which is social media marketing as an intermediate variable/independent variable, which consists of 1) Facebook (Z1), 2) Website (Z2), 3) Instagram (Z3) and 4) Youtube (Z4).

\section{Result and Discusssion \\ Respondent's Demographic}

Base on the 251 questionnaires are distributed, only 181 (72\%) respondents answered and returned the questionnaire, as follows; first, sex catagory; female respondents 149 people (78.42\%) and male 32 people (17.7\%). Second, in terms of education; 52 people $(28.7 \%)$ with a Bachelor degree (S1), 96 people (53\%) with Diploma education (DIII), high school education equivalent to 32 people $(17.7 \%)$ and 1 person $(0.6 \%)$ junior high school education. Third, in terms of age; the youngest respondents were 22 years with 2 people and the oldest respondents 45 years as many as 3 people. 181 respondents, 139 people $(76.8 \%)$ were $<30$ years old. This is the millennial generation that is literate towards technology and social media. Fourth, the most employment status is contract II employees $46.4 \%$ ( 84 people), $32.6 \%$ (59 people) permanent employees and $21 \%$ contract employees I (38 people). Fifth, based on marital status, married respondents were $61.3 \%$ (111 people) while unmarried respondents were $38.7 \%$ (70 people), and sixth, from work units, most of them as a Nursing Division and Midwifery 50.3\% (91 people), then Medical Support Division 30.4\% (55 people), General Division 8.8\%, Finance Division $8.8 \%$ and Marketing Division $1.7 \%$. Distribution based on ril population in this study.

\section{Descripstion Analyses}

Internal Marketing (IM) Variable

Table 1. Job Satisfaction (X1)

\begin{tabular}{llcc}
\hline No & Indicator & \% Unsatisfied & \% Satisfied \\
\hline 1 & $X_{1.1}$ Career Management & 56.7 & 43,3 \\
\hline 2 & $X_{1.2}$ Education and Training & 58,4 & 41,6 \\
\hline 3 & $X_{1.3}$ Reward & 62,8 & 37,2 \\
\hline 4 & $X_{1.4}$ Recruitment System & 62,4 & 37,6 \\
\hline & Average & $\mathbf{6 0 , 1}$ & $\mathbf{3 9 . 9}$ \\
\hline
\end{tabular}

Source : Primary data processed, 2019

In table 1, unsatisfied employees are more than satisfied. The average of $60.1 \%$ is unsatisfied where the greatest dissatisfaction is in the reward system and then in the recruitment system.

Table 2. Customer Satisfaction (X2)

\begin{tabular}{clll}
\hline No & \multicolumn{1}{c}{ Indicators } & \multicolumn{1}{c}{ \% Unsatisfied } & \% Satisfied \\
\hline 1 & $\mathrm{X}_{2.1}$ The Doctor Services & 18,9 & 81,1 \\
\hline 2 & $\mathrm{X}_{2.2}$ Nursery Services & 25,9 & 74,1 \\
\hline 3 & $\mathrm{X}_{2.3}$ Information and Registration Services & 57 & 53 \\
\hline 4 & $\mathrm{X}_{2.4}$ Laboratory Services & 31,5 & 68,5 \\
\hline 5 & $\mathrm{X}_{2.5}$ Radiology Services & 37,1 & 62,9 \\
\hline 6 & $\mathrm{X}_{2.6}$ Financial Services & 44,2 & 55,8 \\
\hline 7 & $\mathrm{X}_{2.7}$ Nutrition/Food Services & 47,5 & 52,5 \\
\hline 8 & $\mathrm{X}_{2.8}$ Pharmacy Services & 47,5 & 52,5 \\
\hline 9 & $\mathrm{X}_{2.9}$ Care Facility & 41,4 & 58,6 \\
\hline & Average & $\mathbf{3 8 , 9}$ & $\mathbf{6 2 , 1}$
\end{tabular}

Source : Primary data processed, 2019

In table 2, showed the doctor services more satisfied by respondent $81,1 \%$ and nursery services $(74,1 \%)$, while the lowest value indicator is nutrition and pharmacy services $(52,5 \%)$, and only difference value on $23,2 \%$. Its mean more respondent satisfied within care program and facility in this hospital based on the result of study. 


\section{Social Media Variable}

Table 3. Social Media (Z)

\begin{tabular}{cllcc}
\hline No & & Indicators & \% Disagre & \% Agree \\
\hline 1 & $Z_{1}$ Facebook & 51,4 & 48,6 \\
\hline 2 & $Z_{2}$ Website & 45,4 & 54,6 \\
\hline 3 & $Z_{3}$ Instagram & 50,8 & 49,2 \\
\hline 4 & $Z_{4}$ Youtube & 49.7 & 50,3 \\
\hline & Average & $\mathbf{4 9 , 3}$ & $\mathbf{5 0 , 7}$ \\
\hline
\end{tabular}

Source : Primary data processed, 2019

In table above showed that social media can affect the patients visit intention, is very thin, only a difference of $0.7 \%$, between disagree and agree.

\section{Patients Visit Intention Variable}

Table 4. Patients Visit Intention (Y)

\begin{tabular}{cllcc}
\hline No & \multicolumn{1}{c}{ Indicators } & \% Disagree & \% Agree \\
\hline 1 & $\mathrm{Y}_{1}$ & Transactional & 20,5 & 79,5 \\
\hline 2 & $\mathrm{Y}_{2}$ & Referential & 16,6 & 83,4 \\
\hline 3 & $\mathrm{Y}_{3}$ Preferential & 17,2 & 82,8 \\
\hline 4 & $\mathrm{Y}_{4}$ Exploratif & 30,5 & 69,5 \\
\hline & Average & $\mathbf{2 1 , 2}$ & $\mathbf{7 8 , 8}$ \\
\hline
\end{tabular}

Source : Primary data processed, 2019

In the table 4 above the average of $78.8 \%$ of respondents agreed to conduct transactional, referential, preferential and explorative responses to Kambang General Hospital.

\section{Inferential Statistic Test}

This study analyzed by Structural Eqyaution Modeling (SEM) as known as partial least squares (PLS).

\section{Outer Model Analyses: Convergent Validity}

Convergent validity is measured through the outer loading where the individual reflective to be high and correlates more than 0.60. Chin (1998) in Ghozali (2006) as an indicator has a good reliability if the loading factor value is greater than 0.70 . While the loading factor of 0.5 to 0.6 can still be maintained for models are still under development. 
Table 5. Outer Loadings Outer Loadings (Mean, STDEV, T-Values)

\begin{tabular}{|c|c|c|c|c|}
\hline & $\begin{array}{c}\text { Original Sample } \\
\text { (O) }\end{array}$ & Sample Mean (M) & $\begin{array}{c}\text { Standard } \\
\text { Deviation (STDEV) }\end{array}$ & $\begin{array}{c}\text { Standard Error } \\
\text { (STERR) }\end{array}$ \\
\hline$X 1.1<-I M$ & 0,659067 & 0,653293 & 0,071508 & 0,071508 \\
\hline $\mathrm{X} 1.2<-\mathrm{IM}$ & 0,635966 & 0,621802 & 0,075480 & 0,075480 \\
\hline $\mathbf{X} 1.3<-$ IM & 0,560800 & 0,556668 & 0,088045 & 0,088045 \\
\hline$X 1.4<-$ IM & 0,680025 & 0,670857 & 0,062650 & 0,062650 \\
\hline$X 2.1<-I M$ & 0,656135 & 0,646720 & 0,081411 & 0,081411 \\
\hline$X 2.2<-$ IM & 0,647109 & 0,647774 & 0,061743 & 0,061743 \\
\hline$X 2.3<-$ IM & 0,752898 & 0,746207 & 0,062135 & 0,062135 \\
\hline$\times 2.4<-$ IM & 0,778686 & 0,777338 & 0,059174 & 0,059174 \\
\hline$X 2.5<-$ IM & 0,806643 & 0,808216 & 0,046555 & 0,046555 \\
\hline$X 2.6<-I M$ & 0,793237 & 0,797066 & 0,047522 & 0,047522 \\
\hline$X 2.7<-$ IM & 0,651703 & 0,651715 & 0,063279 & 0,063279 \\
\hline$X 2.8<-I M$ & 0,643141 & 0,643667 & 0,064717 & 0,064717 \\
\hline$X 2.9<-I M$ & 0,657809 & 0,656427 & 0,064210 & 0,064210 \\
\hline $\mathrm{Y}_{1}<-\mathrm{MK}$ & 0,887432 & 0,889630 & 0,024820 & 0,024820 \\
\hline$Y 2<-M K$ & 0,870150 & 0,866449 & 0,057624 & 0,057624 \\
\hline Y3 $<-$ MK & 0,897942 & 0,895982 & 0,030781 & 0,030781 \\
\hline Y4 <- MK & 0,720033 & 0,721007 & 0,083209 & 0,083209 \\
\hline $21<-S M$ & 0,899606 & 0,902471 & 0,024399 & 0,024399 \\
\hline $22<-S M$ & 0,913072 & 0,913727 & 0,048379 & 0,048379 \\
\hline $23<-S M$ & 0,942706 & 0,942236 & 0,014225 & 0,014225 \\
\hline $24<-S M$ & 0,940260 & 0,939193 & 0,017191 & 0,017191 \\
\hline
\end{tabular}

Source : Primary data processed, 2019

Based on table 5 all of variables the value of the loading factor is greater than 0.6 except for indicator X1.3 of the IM variable which is 0.56. Variable Social Media has the highest loading factor above 0.9. This is means that all indicators of the IM (Internal Marketing), SM (Social Media) and MK (Patient Visit Intention) variables are valid, meaning convergent validity has met the requirements.

\section{Discriminant Validity (Cross Loading)}

Discriminatory validity is one measure to the cross loading correlation test with latent variables. The testing criteria are that the results of cross loading correlation are greater when compared with other latent variables. Cross loading test results explained in the following table. 
Table 6. Results Outer Loading Outer Model T-Statistic

\begin{tabular}{|c|c|c|c|}
\hline & IM & Мк & SM \\
\hline $\mathbf{X 1 . 1}$ & 9,216711 & & \\
\hline$\times 1.2$ & 8,425595 & & \\
\hline $\mathbf{X 1 . 3}$ & 6,369495 & & \\
\hline$\times 1.4$ & 10,854430 & & \\
\hline$\times 2.1$ & 8,059561 & & \\
\hline$\times 2.2$ & 10,480641 & & \\
\hline$\times 2.3$ & 12,117066 & & \\
\hline$\times 2.4$ & 13,159269 & & \\
\hline$\times 2.5$ & 17,326660 & & \\
\hline$\times 2.6$ & 16,691901 & & \\
\hline$\times 2.7$ & 10,298927 & & \\
\hline$\times 2.8$ & 9,937784 & & \\
\hline$\times 2.9$ & 10,244598 & & \\
\hline Y1 & & 35,754251 & \\
\hline $\mathbf{Y 2}$ & & 15,100569 & \\
\hline Y3 & & 29,172358 & \\
\hline Y4 & & 8,653258 & \\
\hline 21 & & & 36,870441 \\
\hline 22 & & & 18,873453 \\
\hline 23 & & & 66,272374 \\
\hline 24 & & & 54,694812 \\
\hline
\end{tabular}

Source : Primary data processed, 2019

In table 6 above the loading value of each item to the construct is greater than the cross loading value. From the results of cross loading analysis and the existing criteria indicate that there are no problems with discriminant validity.

$A V E$

AVE is a measure of discriminant validity. Fornnel \& Larcer, (1981) recommends that AVE must be greater than 0.5 . The AVE value in this study is greater than 0.5 as shown in the following table.

Table 7. $A V E$

\begin{tabular}{ll}
\hline Konstruk & $\boldsymbol{A} \boldsymbol{V E}$ \\
\hline IM & 0,686 \\
\hline MK & 0,844 \\
\hline SM & 0,924 \\
\hline Average & $\mathbf{0 , 8 1 8}$ \\
\hline
\end{tabular}

Source : Primary data processed, 2019

\section{Inner Model}

Inner model is seen from the value of R2 (R-Square), Q2 (Predictive relevance) and GoF (Goodness of Fit). The test of the coefficient of determination or R-squared test (R2) aims to determine how well the inner model (structural model) is formed. According to Hair, (2011) states that if the R2 value is $0.75,0.50$ and 0.25 shows a strong, moderate and weak model. The results of evaluation of structural models with R2 (R-Square), Q2 (Predictive relevance) and GoF (Goodness of Fit) can be shown as follows. 
Table 8. R Squares

\begin{tabular}{ll}
\hline Konstruk & $\boldsymbol{R}$ Squares \\
\hline$S M$ & 0,223 \\
\hline$M K$ & 0,253 \\
\hline $\boldsymbol{R}$ Squares Average & 0,238 \\
\hline
\end{tabular}

Source : Primary data processed, 2019

Based on the value of $\mathrm{R} 2$ on average is 0.238 smaller than 0.25 , the structural model is said to be weak.

\section{2). Predictive Relevance $\left(Q^{2}\right)$}

Predictive relevance $\left(\mathrm{Q}_{2}\right)$, using the formula:

$\mathrm{Q}^{2}=1-\left(1-\mathrm{R}^{2} 1\right)\left(1-\mathrm{R}^{2} 2\right) \ldots \ldots\left(1-\mathrm{R}^{2} \mathrm{p}\right)$

$\mathrm{Q}^{2}=1-\left(1-0,223^{2}\right)\left(1-0,253^{2}\right)$

$\mathrm{Q}^{2}=1-(0,950271)(0,935991)$

$\mathrm{Q}^{2}=1-0,889445=0,110555$

From the results of predictive relevance calculations, the model shows predictive relevance because Q2>0. The model has an ability to predict of influence in latent variables.

\section{3). GoF (Goodness of Fit)}

The last is to find the value of Goodness of Fit $(\mathrm{GoF})$, as follows:

$A V E=\mathbf{0 . 8 1 8}$, rata-rata $R^{2}=\mathbf{0 . 2 3 8}$

$\mathrm{GoF}=\sqrt{A V E \times R 2}$

$\mathrm{GoF}=\sqrt{(0.818)(0.238)}=\mathbf{0 , 4 4 1}$

Based on the results of the GoF calculation manually, a GoF value greater than 0.38 , so the $\mathrm{GoF}$ is categorized as large. From the results of the structural model test (inner model), from the measurements of the R-Squares, Q-Squares and GoF can be categorized, the formed model is robust or strong. Its mean, the hypothesis testing can be done.

\section{Hypothesis Testing}

The hypothesis test is used bootstrapping. The bootstrapping result which is the path coefficient value appears in the following figure:

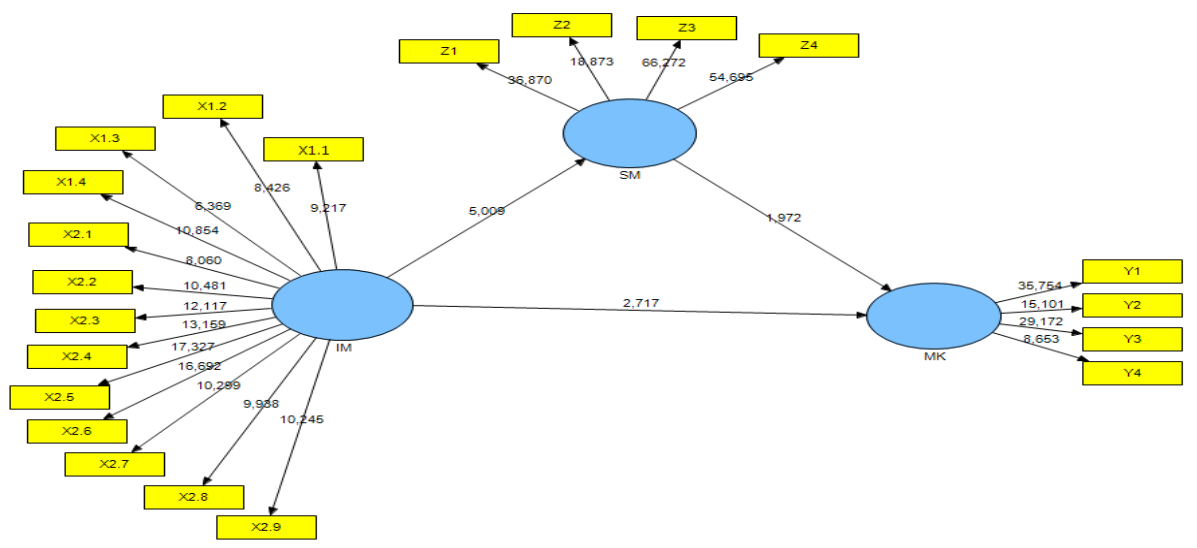

Figure 3. Bootstrapping Model

The figure above can be concluded that; the effect of Internal Marketing Variable (IM) to Patients Visit Intention Variable (MK) has a path coefficient of 0.308214 and significant $(\mathrm{t}=2.717$; $\mathrm{p}<0.05$ ). The effect of Internal Marketing (IM) on Social Media (SM) has a path coefficient of 0.487513 and significant too $(t=5.009 ; \mathrm{p}<0.05)$. The Effect of Social Media (SM) on the Patients Visit Intention (MK) has a path coefficient of 0.281040 and significant $(t=1.972 ; \mathrm{p}<0.05)$. Effect of Internal Marketing (IM) on Patients Visit Intention (MK) through Social Media marketing cannot be measured using the Path Coefficients table. This indirect relationship is measured using the Sobel test, and the result $\mathrm{Z}=1.835331$ where the effect is significant at $\mathrm{p}<0.1$ 


\section{Discussion}

In hypothesis test 1 , the internal marketing effects on social media with a path coefficient of 0.308 and a significant $t$ value of 5.009. The implication of this study is the employee satisfaction and patient satisfaction must be focus on hospital's management work. This result is same with previous reseach of Catalin et al (2014), Rafiq and Ahmed (2000), Ballantyne (2000), Gronroos (1990), Berry (1981), that organizations cannot satisfy customers if they are not satisfying an employees. Therefore, the basic requirements is carried out by the organization for internal marketing implementation within it as an organizational goal, and involvement of management and employees in activities, as well as effective internal communication in organization and ongoing control for corrective act.

In the hypothesis test 2 , the social media influences patients visit intention in the path coefficient of 0.281 and $t$ value of 1.972 . As a social media, Instagram and Youtube are most widely used by young people of respondents in this study $(76.8 \%)$ aged $<30$ years or millennial generation where they are technology and social media litearte. Philip Kotler (2012), the pattern of marketing through social media allows interaction between producers and consumers for their products. When the customers satisfied, they will be share it to other. From this study, the hospital management have to manage its social media account creatively to increase of patient visit intention, especially on Instagram.

In hypothesis 3, the internal marketing effects on patients visit intention is significant thru path coefficients at 0.308 and t statistics 2.717. The highest value on the transactional (Y1), preferential (Y3), referential (Y2) and exploratory (Y4) indicators. The patient's wants revisit and prefers to Kambang Hospital because they are feel satisfied on services and products at Kambang General Hospital. According to the theory of Zeithaaml, et al (2006), the service quality, product quality and price are determinants of customer satisfaction or patient satisfaction will invite other larger customers and high financial returns for hospitals in competition. This research shows that the hospital management must to be make a policies and strategies to improve employee satisfaction and patient satisfaction because employees and patients are internal marketers who can increase an patients visit intention.

The hypothesis 4 , internal marketing influences the patients visit intention through social media marketing. The hypothesis test used by Sobel formula test. The Sobel count test of 1.835 to be significant at $\mathrm{p}<0.1$. So, in this study hospitals management must be manage and make policies to increase an internal marketing through employee satisfaction and patient satisfaction. Now, in digital era, the role of social media was very important. So the management of Kambang General Hospital had to manage social media continuously, because social media marketing had an influence on patient's visits intention in Kambang Hospital.

\section{Conclusion}

From the models used and the results of this research, obtained can be concluded as follows: Internal marketing which is formed from two dimensions, namely employee satisfaction and patient satisfaction, an influence on Social Media such as Facebook, Website, Instagram, and Youtube, and influence to on Patients Visit Intention. Internal marketing directly influences patient's visit intention which consist of 4 dimensions, namely transactional, refrential, preferential and explorative interests. Social Media mediated an Internal Marketing and significant effect to Patient's Visit Intention.

\section{Suggestion}

The suggestion from the results of this study on marketing management, especially in hospital marketing management are follows: 1) policies and management regulations most an important in Kambang General Hospital and focused both of an employee satisfaction or patient satisfaction. This research proves that patient's visit intention will be increasing when an employee satisfaction and patient satisfaction are match and correlated both of them. 2) Social media as a media promotion must be managed by professionally. So it can have a maximum an economics return and impact on increasing patient's visit intention whithin it.

\section{References}

Abzari, M., Ghorbani, H., (2011), The Effect of Internal Marketing on Organizational Commitment from Market Orientation Viewpoint in Hotel Industry in Iran, International Journal of Marketing Studies, Vol.3, No. 1. 
Arnett, D. B., Laverie, D. A. and McLane, C. (2002). Using job satisfaction and pride as internalmarketing tools. The Cornell Hotel and Restaurant Administration Quarterly, 43(2), 87-96.

Ahmed, P.K., Rafiq, M., (1995), The role of internal marketing in the implementation of marketing strategies, Journal if Marketing Science, Vol 1(4), pp 35-51.

Ahmed, P. K. and Rafiq, M. (2002). Internal Marketing: Tools and Concepts for Customer-focused Management. New York: Routledge.

Ahmed, P. K., Rafiq, M., Internal Marketing Issues and Challenges, (2003), European Journal of Marketing Vol. 37 No. 9, 2003 pp. 1177-1186 MCB UP Limited 0309-0566 DOI 10.1108/03090560310498813

Ahmed, K., Rafiq, Pervaiz, K., M., Saad, N. M., (2003), Internal Marketing and the Mediating Role of Organisational Competencies, European Journal of Marketing, Vol. 37, No. 9, 2003, pp 1221-1241, DOI 10.1108/0309560310486960

Ahmad, A. E. M. K. and Al-Borie, H. M. (2012). Impact of internal marketing on job satisfaction and organizational commitment: A study of teaching hospitals in Saudi Arabia. Business and Management Research, 1(3), 82-94.

Azedo, D., Alves,H., (2014), Internal marketing practices in health care and their influence on Nursemotivation, Home Care Management \& Practice, 26 (2), pp 92-100, doi: $10.1177 / 1084822313508647$.

Beall,T., Wayman,J.,et al, (2012), Social marketing at a critical turning point, Journal of Social Marketing, Vol, 2 Issue 2, pp 103-117. Doi: 10.1108/20426761211243946.

Bhaskari, N.L., Kumar, S.N.S., Subhashini, M.M.,..et al, (2012), Relationship Marketing, Journal of Business and Management, Vol 3 Iss 6 pp. 46-48

Bashar, A., Ahmad,I., Wasiq,M., (2012), Effectiveness of ocial Media as a Marketing Tool: an Emperical Study, International Journal of Marketing, Financial Services \& Management Research, Vol.1, Issue 11, Online available at www.indianresearchjournals.com

Barger,V.A., Peltier,J.,..et al, (2016), Social media and costumer engagement: a review and research agenda, Journal of Interactive Marketing, 10(4), htpp:dx.doi.org/10.1108/JRIM06-2016-0065.

Emmanuel, A., Wali, A.F., (2013), Internal Marketing Strategy and Employee Performance, European Journal of Business and Management (online) Vol.5, No.31, www.iiste.org ISSN 2222-1905.

Grosberg,K.A., (2016), The new marketing solutions that will drive strategy implementation, Journal Strategy \& Leadership, 44(3) 20-26. Doi: 10.1108/SL-04-2016-0018.

Gronroos, C. (1981). Internal Marketing - An Integral Part of Marketing Theory, in J.H. Donelly and W.R. George (Eds.), Marketing of Services, pp.236-238. American Marketing Association Proceedings Series.

Gronroos, C. (1990). Service Management and Marketing: Managing the Moments of Truth in Service Competition. Lexington, MA: Lexington Books.

Gummesson, E. (2000). Internal Marketing in the Light of Relationship Marketing and Network Organizations, in R.J. Varey and B.R. Lewis (Eds.), Internal Marketing: Directions for Management, pp. 27-42. London:Routledge

Househ,M., Borycki,E., Kushniruk,A., (2014), Empowering patients through social media: The benefits and challanges, Health Information Journal, 20(50) 50-58. Doi: $110.1177 / 1460458213476969$.

Hussein, A.S. (2015), Penelitian bisnis dan manajemen menggunakan Partial Least Squares (PLS) dengan smartPLS3.0. Universitas Brawijaya, Jurusan Manajemen Fakultas Ekonomi dan Bisnis.

Info BPJS Media Eksterna BPJS Kesehatan, Edisi 44, (2016), https://www.bpjs kesehatan.go.id/bpjs/dmdocuments/4dc1390e3f9ad849198c0321a7c4bdc0.pdf. (diunduh 20 November 2018)

Keinanen,H., Kuivalainen,O., (2015), Antecedents of social media B2B use in industrial marketing context: customer's view, Journal of Business \& Industrial Marketing, 30(6) 711-722. Doi: 10.1108/JBIM-04-2013-0095.

Kotler, P. (2008). Prinsip - Prinsip Pemasaran. Alih bahasa Bob Sabran, Editor Adi Maulana dari Principles of Marketing. Jakarta : Erlangga.

Kotler, P \& Keller, KL. (2008). Manajemen Pemasaran, Edisi Ketiga Belas. Alih bahasa Bob Sabran, Editor Adi Maulana dari Marketing Management, Thirteenth edition. Jakarta : Erlangga. 
Kotler, P. (1997). Manajemen Pemasaran, Analisis, Perencanaan, Implementasi dan Kontrol, Alih bahasa : Hendra Teguh jilid 1 dan 2 edisi Indonesia, Jakarta : PT Ikrar Mandiri Abadi.

Koumpourosa, Y., Touliasa,T.L.,Koumpouros,N.(2015), The importance of patient engagement and the use of Social Media marketing in healthcare, Technology and Health Care 23 495-507 495 DOI 10.3233/THC-150918.

Kautish,S., Kochhar,N., (2017), Handbook of social media enabled marketing, Melalui https://www.researchgate.net/publication/318645779

Kompas.com. Berapa Pengguna Internet di Indonesia. Melalui $<$ https://tekno.kompas.com/read/2018/02/22/16453177/berapa-jumlah-penggunainternet-indonesia.> [25/5/2018]

Luo, L., Wang,Y., Han,L. (2013), Marketing via social media; a case study, Library Hi Tech,31(3), 455-466. Doi: 10.1108/LHT-12-2012-0141

Long, X., Qi,L.,..et al, (2017), Evolving use of social media among Chinese urologist: Opportunity or challange?, PloS One, 12(7), Doi:10.1371/journal.pone,0181895

Lings, Ian (2001) Internal marketing and supply chain management. Journal of ServicesMarketing, 14(1), pp. 2743 http://dx.doi.org/10.1108/08876040010309194.

Mishra, S., (2010), Internal Marketing - A Tool to Harness Employees' Power in Service Organizationsin India, Journal of Business and Management

Mukherjee,A., Ginnis,J.Mc., (2007), E-healthcare: an analysis of key themes in research, International Journal of Pharmaceutical and Helathcare Marketing, 1(4) 349-363. Doi: 10.1108/17506120710840170.

Patino,A., Pitta,D.A.,..et al, (2012), Marketing developments; Social media's emerging importance in market research, Journal of Consumer Marketing, 29(3) 233-237. Doi: $10.1108 / 07363761211221800$.

Rader,C.S., Subhan,Z.,..et al, (2014), Emerging social media marketing strategy for pharmaceuticals, International Journal of Pharmaceutical and Healthcare Marketing, 8(2) 193-225. Doi: 10.1108/IJPHM-05-2013-0027.

Robbins, Stephen P. 2001. Perilaku Organisasi: Konsep, Kontroversi, Aplikasi, Jilid 1, Edisi 8, Prenhallindo, Jakarta.

Samen,A.A., Alshurideh,M. (2012), The Impact of Internal Marketing on Internal Service Quality: A Case Study in a Jordanian Pharmaceutical Company. International Journal of Business and Management; Vol. 7, No. 19; 2012, ISSN 1833-3850 E-ISSN 1833-8119, Published by Canadian Center of Science and Education.

Sotiriadis,M.D., (2017), Sharing tourism experiences in social media. A literature review and set of suggested business strategies, International Journal of Contemporary Hospitality Managements, 29(1) 179-225. Doi: 10-1108/TJCHM-05-2016-0300. 